\title{
Regulation of the Enzymes of the Hydroaromatic Pathway in Acinetobacter calco-aceticus
}

\author{
By W. M. INGLEDEW, M. ELENA F. TRESGUERRES \\ AND J. L. CÁNOVAS \\ Instituto de Biología Celular, Consejo Superior de Investigaciones \\ Científicas, Velázquez I44, Madrid-6, Spain
}

(Accepted for publication 2I July 1971)

\begin{abstract}
SUMMAR Y
The synthesis of dehydroquinase, dehydroshikimate dehydrase and the other enzyme of the hydroaromatic pathway, the hydroaromatic dehydrogenase, was product-induced by protocatechuate in Acinetobacter calco-aceticus. The enzymes of the hydroaromatic pathway and those which subsequently break down protocatechuate are subject to a high degree of coordinate control.

Two dehydroquinase isoenzymes exist. The isoenzyme induced by protocatechuate is required for growth on quinate but plays no role in the biosynthesis of aromatic compounds.
\end{abstract}

\section{INTRODUCTION}

The biochemistry of the microbial assimilation of the hydroaromatic compounds quinate and shikimate has been reviewed by a number of authors (Tatum, Gross, Ehrensvärd \& Garnjobst, 1954; Mitsuhashi \& Davis, I954 b; Gross, I958; Hattori, Yoshida \& Hasegawa, I958; Rogoff, I958; Yano \& Arima, I958; Yoshida I964; Tresguerres, de Torrontegui \& Cánovas, 1970). Degradation of these compounds appears to occur via the aromatic intermediate, protocatechuate (Fig. I).

In most organisms the first obligate oxidative steps of the hydroaromatic pathway are mediated by specific dehydrogenases. However, in Acinetobacter calco-aceticus, genetic and biochemical evidence indicated the existence of a single protein catalysing the oxidation of both quinate and shikimate. This enzyme is associated with subcellular particles and is independent of pyridine nucleotides (Tresguerres, de Torrontegui \& Cánovas, 1970; Tresguerres, de Torrontegui, Ingledew \& Cánovas, 1970). Dehydroshikimate dehydrase catalyses the dehydration of 5-dehydroshikimate to protocatechuate (Gross, 1958). Quinate catabolism requires, in addition, dehydroquinase, an enzyme which converts 5-dehydroquinate into 5-dehydroshikimate. These two intermediates are also involved in the biosynthesis of aromatic amino-acids and vitamins. Fungi possess an inducible catabolic dehydroquinase distinct from the biosynthetic isoenzyme (Ahmed \& Giles, 1969) but only one kind of dehydroquinase appears in bacteria (Berlyn \& Giles, I969), even though dehydroquinase activity is increased in some of them by growth on quinate (Mitsuhashi \& Davis, I954).

We have previously examined in Acinetobacter calco-aceticus the regulation of the hydroaromatic dehydrogenase (Tresguerres, de Torrontegui et al. 1970) and of the enzymes which break down protocatechuate into succinate and acetyl-CoA (Cánovas \& Stanier, 1967; Cánovas, Wheelis \& Stanier, 1968; Cánovas, Johnson \& Wheelis, 1968; Cánovas \& Johnson, I968). The synthesis of all these enzymes is governed by protocatechuate and seems to be 
subject to a high degree of coordination. This paper reports the regulation of the other enzymes, dehydroquinase and dehydroshikimate dehydrase, which are active in the conversion of hydroaromatic compounds into protocatechuate.

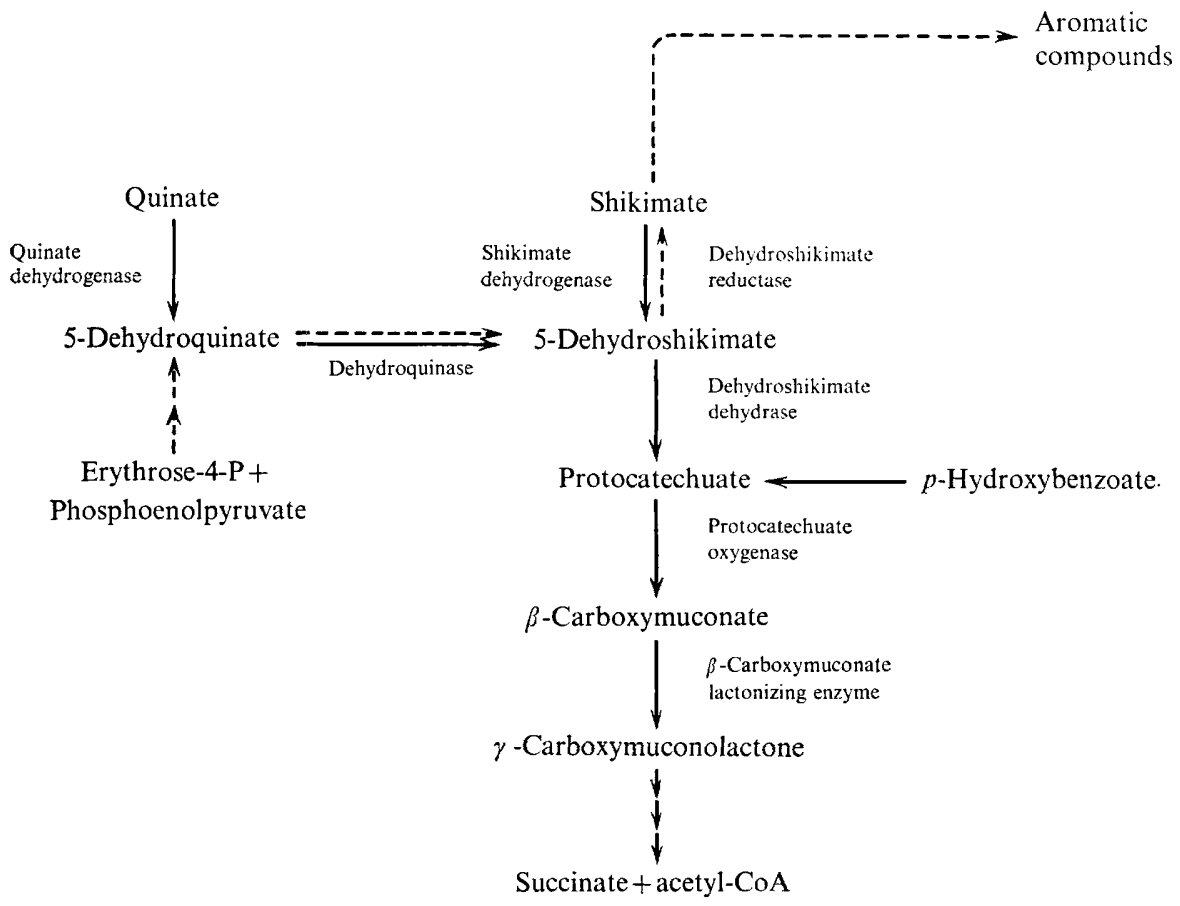

Fig. I. A diagram to illustrate the conversion of quinate and shikimate into protocatechuate and the subsequent degradation of this compound into succinate and acetyl-CoA (solid arrows). The metabolic interrelationships between these dissimilative routes and the aromatic biosynthetic pathway (broken arrows) are also represented.

\section{METHODS}

Microbiological procedures. Strain 73 of Acinetobacter calco-aceticus was from the Collection of the Department of Bacteriology and Immunology, University of California, Berkeley, U.S.A. The isolation and characteristics of mutants 2 P (Cánovas \& Stanier, I 967) and POC-5 (Cánovas, Johnson \& Wheelis, I968) have been described before. Other auxotrophs and revertants were obtained by nitrosoguanidine treatment conducted as follows: exponentially growing cells were harvested from succinate minimal medium and resuspended at approximately $4.5 \times 10^{8}$ viable bacteria $/ \mathrm{ml}$. in sterile 0.0 I M-sodium citrate buffer $\mathrm{pH} 5.5$, containing 50 to $100 \mu \mathrm{g}$. $N$-methyl- $N^{\prime}$-nitro- $N$-nitrosoguanidine $/ \mathrm{ml}$. The suspension was gently shaken for $30 \mathrm{~min}$. at $30^{\circ}$, the bacteria centrifuged, washed with $0^{\circ} \mathrm{I} \mathrm{M}$-phosphate buffer pH 6.8 and resuspended in the same buffer. Two distinct procedures were used to select for mutants in the hydroaromatic pathway. (I) Nitrosoguanidine-treated populations of strain $2 \mathrm{P}$ were plated on mineral medium containing a growth limiting amount of succinate ( $2 \mathrm{~mm})$, Io $\mathrm{mm}$ quinate and $2 \%(\mathrm{v} / \mathrm{v})$ of an iron-EDTA solution prepared according to Arnon, Das \& Anderson, (1963). The parent strain 2P, defective in protocatechuate oxygenase, accumulated protocatechuate and formed colonies with the typical blue colour characteristic of the chelates of polyphenol and iron. Colonies unable to convert quinate into protocatechuate were 
white and small, because they could only use succinate for growth. Revertants with restored protocatechuate oxygenase activity also formed white colonies but they were bigger because they assimilated both quinate and succinate. Among the mutants isolated by this procedure were strains NP9, DP I5 and NP3. (2) According to Guerola, Ingraham \& Cerdá-Olmedo (1971), up to $3 \%$ of the nitrosoguanidine-induced mutants of Escherichia coli in a given gene suffer a simultaneous mutation in a closely linked gene. Therefore, the selection of a certain mutant ought to be simplified by searching among the revertants of a strain blocked in a linked gene after a suitable nitrosoguanidine treatment. Data reported in this paper show the existence of close analogies in the regulation of protocatechuate oxygenase and the enzymes of the hydroaromatic pathway, suggesting that the structural genes for these enzymes could be associated in the chromosome. Consequently, we looked for strains deficient in the conversion of quinate into protocatechuate among the nitrosoguanidine-induced revertants from mutant $2 \mathbf{P}$ which had restored protocatechuate oxygenase activity. Simple revertants were expected to grow on either $p$-hydroxybenzoate or quinate. Double mutants should only recover the ability to grow on $p$-hydroxybenzoate but not on quinate. Three of the hydroaromatic auxotrophs isolated by this method, strains $2 \mathrm{P}-242,2 \mathrm{P}-318$ and $2 \mathrm{P}-344$ have been used in this work. The media and conditions of cultivation employed have been described before (Cánovas \& Stanier, 1967).

Preparation of cell-free extracts and enzyme assays. The procedures of Tresguerres, de Torrontegui \& Cánovas, (1970) were employed to prepare extracts by ultrasonic treatment and to assay enzymes. In the present work, two additional enzymes were assayed. The assay mixture for dehydroquinase contained in $3 \mathrm{ml}$.: enzyme; $100 \mu$ moles tris buffer ( $\mathrm{pH} \mathrm{8.0)} \mathrm{and} 0.24 \mu$ mole of 5 -dehydroquinate. An increase of 3.96 absorbancy units at $234 \mathrm{~nm}$. corresponded to the formation of $1 \cdot 0 \mu$ mole of 5 -dehydroshikimate (Mitsuhashi \& Davis, 1954a). To assay dehydroshikimate dehydrase the reaction mixture contained

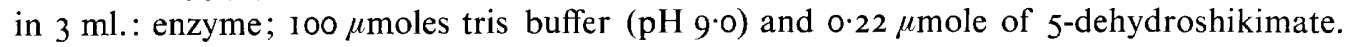
Under these conditions, the formation of $1.0 \mu$ mole of protocatechuate produced an increase of $\mathrm{I} \cdot 28$ extinction units at $290 \mathrm{~nm}$.

The experiments on the kinetics of thermal inactivation of dehydroquinase were conducted as outlined previously (Cánovas \& Stanier, 1967).

Chemical methods. 5-Dehydroquinic and 5-dehydroshikimic acids were prepared by platinum-catalysed dehydrogenation of quinic and shikimic acids respectively, according to Haslam, Haworth \& Knowles (1963). Their report also describes a method for the identification of the products. 5-Dehydroshikimate was assayed spectrophotometrically at $234 \mathrm{~nm}$., at which wavelength its molar extinction coefficient equals I I,900 (Mitsuhashi \& Davis, $1954 a$ ). The same method served to estimate 5-dehydroquinate after converting it quantitatively to 5-dehydroshikimate using a dehydroshikimate dehydrase-free preparation of dehydroquinase, obtained by heating, at $50^{\circ}$ for Io min., extracts from wild-type organisms grown on quinate.

Protein was estimated by the method of Lowry, Rosebrough, Farr \& Randall (I95I).

\section{RESULTS}

Pattern of induction of dehydroquinase and dehydroshikimate dehydrase. The effect of various growth substrates on the levels of dehydroquinase and dehydroshikimate dehydrase in extracts of wild-type Acinetobacter calco-aceticus is shown in Table 1. Their specific activities in organisms grown on quinate were 20 to 40 times higher than in organisms grown on succinate. The other hydroaromatic compound that can be used as carbon source by 
these bacteria, shikimate, also elicited full synthesis of both enzymes. However, synthesis of these enzymes was not induced only during growth on hydroaromatic compounds, as was indicated by their activities in extracts from organisms grown on $p$-hydroxybenzoate or protocatechuate (Table I). These findings suggested that the synthesis of the enzymes was

Table I. Levels of dehydroquinase and dehydroshikimate dehydrase in cell-free extracts of Acinetobacter calco-aceticus strain 73 grown on the substrates indicated

Enzyme activities in $\mu$ moles transformed/min./mg. protein.

\begin{tabular}{|c|c|c|c|c|}
\hline & \multicolumn{4}{|c|}{ Substrate used for growth } \\
\hline & $\begin{array}{r}\text { Succinate } \\
(20 \mathrm{mM})\end{array}$ & $\begin{array}{l}\text { Quinate } \\
\text { ( Io mM) }\end{array}$ & $\begin{array}{c}p \text {-Hydroxyben- } \\
\text { zoate } \\
\text { (10 } \mathrm{mM})\end{array}$ & $\begin{array}{l}\text { Protocatechuate* } \\
\qquad(2 \mathrm{~mm})\end{array}$ \\
\hline Dehydroquinase & 0.006 & 0.120 & 0.153 & 0.160 \\
\hline $\begin{array}{l}\text { Dehydroshikimate } \\
\text { dehydrase }\end{array}$ & 0.044 & $I \cdot 230$ & $1 \cdot 590$ & {$[\cdot 750$} \\
\hline
\end{tabular}

* Higher concentrations were avoided to minimize toxicity. Successive additions of this substrate were made when it was consumed as shown by the disappearance of the blue colour due to the iron and protocatechuate chelate.

not governed by their substrates which cannot be formed during growth on aromatic compounds (Cánovas, Wheelis \& Stanier, I 968), but was more probably controlled through product induction by protocatechuate or a metabolite derived from it. The latter possibility was tested by studying the behaviour of mutants of $A$. calco-aceticus which have no protocatechuate oxygenase activity and therefore cannot degrade protocatechuate. Cánovas, Wheelis \& Stanier (1968) and Cánovas, Johnson \& Wheelis (I 968) showed that these strains possess an elevated intracellular content of protocatechuate. Consequently all the enzymes governed by protocatechuate are synthesized at maximum rate by these protocatechuate oxygenase-deficient mutants. even in the absence of an exogenous source of aromatic or hydroaromatic substances. The same effect has been seen for the synthesis of dehydroquinase and dehydroshikimate dehydrase (values for strain $2 \mathrm{P}$ are reported in Table 3 ). 3 -Hydroxy4-methylbenzoate also completely inhibited the apparently constitutive synthesis of both enzymes in these mutants. This compound, a non-metabolizable analogue of protocatechuate, acts by inhibiting all known inductive processes governed by protocatechuate (Cánovas, Johnson \& Wheelis, 1968).

Evidence for two isoenzymes with dehydroquinase activity. The conversion of 5-dehydroquinate into 5-dehydroshikimate is a necessary step in both quinate catabolism and the biosynthesis of aromatic amino acids. The synthesis of elevated levels of dehydroquinase, the enzyme catalysing this process, seems to be governed by protocatechuate. However, it is very unlikely that this compound has any role in the control of the biosynthetic route. Besides, dehydroquinase activity increased under induction conditions significantly less than did all other enzymic activities which are also controlled by protocatechuate, as shown in Table I and in previous reports (Cánovas \& Stanier, 1967; Tresguerres, de Torrontegui et al. 1970). A plausible way to interpret this situation is to postulate the existence of two dehydroquinase isoenzymes, one of which is not regulated by protocatechuate and operates in the biosynthetic process.

Among the nitrosoguanidine induced revertants of $2 \mathrm{P}$ with restored ability to grow on $p$-hydroxybenzoate and shikimate, we isolated three (strains 2 P-242, 2 P-3 I 8 and 2 P-344) which were still unable to grow on quinate. The synthesis of dehydroquinase by these strains 
was independent of the presence of protocatechuate. The results for strain $2 \mathrm{P}-242$ are reported in Table 2 . When grown without aromatic or hydroaromatic compounds, the levels of enzymes which mediate the conversion of quinate into protocatechuate, including dehydroquinase, were equal to those in wild-type organisms. The synthesis of the dehydrogenase and dehydroshikimate dehydrase was strongly enhanced in $2 \mathrm{P}-242$ by protocatechuate or shikimate, but dehydroquinase activity remained unchanged. Basal levels of the three enzymes were measured in bacteria grown with quinate. Similar results were obtained with the two other mutants of identical phenotype. These organisms grew normally on succinate, with no requirement for hydroaromatic or aromatic compounds, which showed that the lack of inducible dehydroquinase did not affect the biosynthesis of aromatic amino acids and vitamins.

Table 2. Enzymes of the hydroaromatic pathway in extracts of strain $2 \mathrm{P}-242$, a mutant unable to grow on quinate

The organisms were grown on $20 \mathrm{~mm}$-succinate. Where indicated, different inducers were also added to $2 \mathrm{~mm}$. Enzyme activities in $\mu$ moles transformed $/ \mathrm{min} . / \mathrm{mg}$. protein.

\begin{tabular}{ccccc} 
Enzyme & \multicolumn{4}{c}{ Inducer } \\
\cline { 2 - 4 } & None & Protocatechuate & Shikimate & Quinate \\
$\begin{array}{c}\text { Hydroaromatic } \\
\text { dehydrogenase }\end{array}$ & 0.01 & $0.4 \mathrm{I}$ & 0.37 & $0.0 \mathrm{I}$ \\
$\begin{array}{c}\text { Dehydroquinase } \\
\begin{array}{c}\text { Dehydroshikimate } \\
\text { dehydrase }\end{array}\end{array}$ & 0.01 & 0.01 & 0.01 & 0.01 \\
& 0.04 & 1.38 & 0.97 & 0.05
\end{tabular}

A simple and sensitive method of differentiating between two isofunctional enzymes is to demonstrate differing kinetics of thermal inactivation. This test was accordingly performed on crude extracts of Acinetobacter calco-aceticus grown on succinate with or without protocatechuate (Fig. 2). Dehydroquinase activity was more stable in extracts from non-induced organisms than in extracts from those grown with protocatechuate. Such a differential thermal denaturation could be due to presence of isoenzymes or to a conformational change within a single protein, induced by protocatechuate itself or a product of its metabolism. To exclude this latter possibility, the same experiment was carried out with one of the strains lacking inducible dehydroquinase activity, mutant $2 \mathrm{P}-242$, grown with protocatechuate. The results, also given in Fig. 2, showed that dehydroquinase activity from these organisms was clearly thermostable. Similar results were obtained for the pleiotropic mutant DP I 5, a strain with no hydroaromatic enzymes but still possessing a biosynthetic dehydroquinase.

We conclude that Acinetobacter calco-aceticus can synthesize two different proteins with dehydroquinase activity; a thermolabile isoenzyme which is only present in induced organisms and is required for growth on quinate, and a thermostable protein which catalyzes 5-dehydroshikimate formation for the biosynthesis of aromatic compounds.

Pleiotropic mutations affecting the degradation of hydroaromatic compounds. We also studied the synthesis of the enzymes of the hydroaromatic pathway by members of a group of pleiotropic mutants. Strains blocked in this pathway were selected from mutant $2 \mathrm{P}$ because they do not accumulate protocatechuate when growing on succinate in the presence of quinate (see Methods). Strain NP9 was an interesting mutant isolated by this method. Data summarized in Table 3 showed that this mutant is still protocatechuate oxygenasedeficient, as was its parent strain, but was no longer endogenously induced for the enzymes governed by protocatechuate. Table 3 includes values for the three enzymes of the hydroaromatic pathway and two enzymes of the protocatechuate branch of the $\beta$-ketoadipate 
pathway, protocatechuate oxygenase and $\beta$-carboxy-cis,cis-muconate lactonizing enzyme. The rate of synthesis of all these enzyme was much lower in NP 9 than in 2 P, even with exogenous protocatechuate. We also observed that inducible dehydroquinase activity was completely absent. Experiments designed to restore the abilities lost by strain NP9 were conducted in an attempt to discover its genetic lesion. Revertant substrains able once again

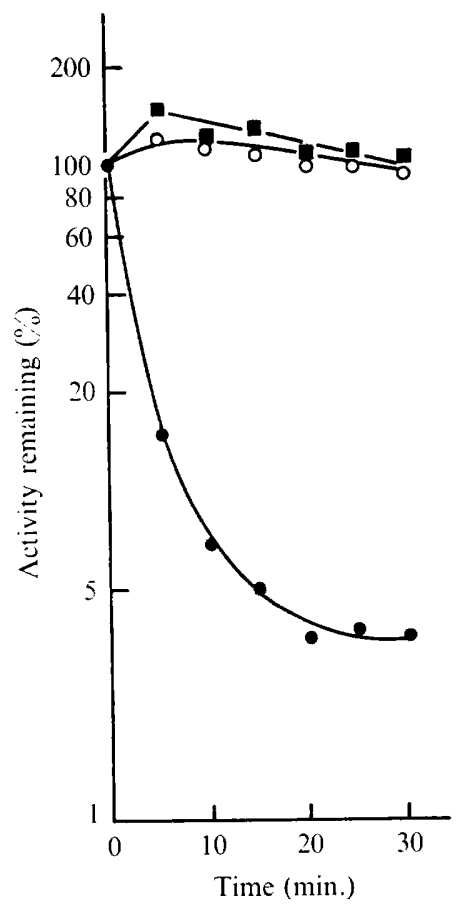

Fig. 2. The kinetics of thermal inactivation at $55^{\circ}$ of dehydroquinase activity in crude extracts from cells of Acinetobacter calco-aceticus. Organisms were grown on $20 \mathrm{~mm}$-succinate. Induction was achieved by adding $2 \mathrm{~mm}$-protocatechuate to the culture medium. $\bigcirc-\mathrm{O}$, Non-induced wild-type; $-\square$, induced wild-type; $\square$, induced 2 P-242.

Table 3. Enzymatic analysis of strain NP9, compared with that of the parent strain $2 \mathrm{P}$

Enzyme activities in $\mu$ moles transformed $/ \mathrm{min} . / \mathrm{mg}$. protein.

\begin{tabular}{|c|c|c|c|c|}
\hline \multirow[b]{3}{*}{ Enzyme } & \multicolumn{4}{|c|}{ Conditions of growth } \\
\hline & \multicolumn{2}{|c|}{ Succinate $(20 \mathrm{~mm})$} & \multicolumn{2}{|c|}{$\begin{array}{c}\text { Succinate }(20 \mathrm{~mm})+ \\
\text { protocatechuate }(2 \mathrm{~mm})\end{array}$} \\
\hline & NP 9 & $2 P$ & NP 9 & $2 \mathrm{P}$ \\
\hline $\begin{array}{l}\text { daromatic } \\
\text { drogenase }\end{array}$ & 0.003 & 0.565 & 0.019 & 0.760 \\
\hline Aroquinase & 0.010 & 0.223 & 0.009 & 0.324 \\
\hline $\begin{array}{l}\text { droshikimate } \\
\text { drase }\end{array}$ & 0.010 & $3 \cdot 170$ & 0.160 & $4 \cdot 450$ \\
\hline $\begin{array}{l}\text { catechuate } \\
\text { enase }\end{array}$ & $<0.001$ & $<0.001$ & $<0.00 \mathrm{I}$ & $<0.001$ \\
\hline $\begin{array}{l}\text { xymuconate } \\
\text { nizing enzyme }\end{array}$ & 0.009 & $I \cdot 620$ & 0.086 & $2 \cdot 450$ \\
\hline
\end{tabular}

Hydroaromatic dehydrogenase

Dehydroquinase Dehydroshikimate dehydrase

Protocatechuate

Carboxymuconate lactonizing enzyme 
to grow on $p$-hydroxybenzoate, could be isolated: the enzyme levels in one of these revertants, strain NP 9-I, are listed in Table 4. Protocatechuate oxygenase activity was present but at a relatively low level. However, the levels of the other enzymes induced by protocatechuate were equally low. This explained the restored capacity to grow, though rather slowly, on $p$-hydroxybenzoate. Quinate could not be used as carbon source for growth by NP9-I mainly because inducible dehydroquinase was still missing.

The inability of this strain to grow on shikimate is less easily explained. We assume that the mutation affecting full expression of the genes governed by protocatechuate also interferes with the synthesis of effective amounts of the inducer from shikimate. This interpretation is supported by two facts: (i) strain NP 9 was no longer apparently constitutive for the enzymes controlled by protocatechuate as are other strains lacking protocatechuate oxygenase; (ii) NP 9-I easily recovered the ability to grow on shikimate, and the generation times of these revertants on either shikimate or $p$-hydroxybenzoate was comparable to those of the wild-type strain. An enzymic analysis of strain NP 9-3, a representative of those revertants able to grow on shikimate, is given in Table 4 . The activities of all the enzymes induced by protocatechuate, except dehydroquinase, were restored to their maximum levels. NP 9-3, in contrast to NP9-I, could be forced to revert on quinate, thereby recovering the ability to synthesize inducible dehydroquinase.

Table 4. Enzymatic analysis of strains NP9-1 and NP9-3

Cells were grown on succinate $(20 \mathrm{~mm})$ in the presence of protocatechuate $(2 \mathrm{~mm})$. Enzyme activities in $\mu$ moles transformed $/ \mathrm{min} . / \mathrm{mg}$. protein.

Enzyme

Hydroaromatic dehydrogenase

Dehydroquinase

Dehydroshikimate dehydrase

Protocatechuate oxygenase

Carboxymuconate lactonizing enzyme

$\begin{array}{cc}\text { NP 9-I } & \text { NP 9-3 } \\ 0.03 & 0.39 \\ 0.01 & 0.01 \\ 0.24 & 1.52 \\ 0.01 & 0.28 \\ 0.14 & 1.66\end{array}$

In summary, strain NP 9 harbours three independent mutations that can be cured with nitrosoguanidine: (i) the original lesion at the structural gene of protocatechuate oxygenase; (ii) the mutation blocking dehydroquinase activity; and (iii) a pleiotropic mutation that interferes with full expression of the genes governed by protocatechuate, most probably therefore affecting a regulatory gene.

A different class of mutants isolated from $2 \mathrm{P}$ by the same procedure as NP 9 is represented by strains DP I 5 and NP3. These mutants were also unable to accumulate protocatechuate when incubated in the presence of hydroaromatic compounds, although they were still protocatechuate oxygenase-deficient. Mutant DP I 5 further differed from the parent organism and from NP 3 in that it did not grow on benzoate or tryptophan, substrates that are catabolized through the catechol branch of the $\beta$-ketoadipate pathway. Enzymic analysis of DP 15 and NP 3 showed that they had completely lost those enzymes governed by protocatechuate. Values for strain DP 15 are reported in Table 5. Even basal enzyme levels were clearly lower than in the wild type. Furthermore, the enzymic activities were not increased by growth with protocatechuate. Identical results have been obtained with strain NP3. These mutants also confirm the existence in Acinetobacter calco-aceticus of two isoenzymes of dehydroquinase, for only the basal level of dehydroquinase remained in these strains, enabling them to perform the synthesis de novo of aromatic aminoacids. Neither DP I5 nor NP 3 could, spontaneously or by nitrosoguanidine treatment, be forced to recover the ability to grow on 
either shikimate, quinate or $p$-hydroxybenzoate. Moreover, the ability to convert quinate into protocatechuate (detected by the formation of blue colonies on the medium containing iron-EDTA plus quinate and succinate), could not be restored. Revertants of DP I 5 able to grow on benzoate were also not obtained.

Finally, we studied the synthesis of dehydroquinase and dehydroshikimate dehydrase by a group of regulatory mutants isolated during previous work. In these organisms (POC series) the ability to induce hydroaromatic dehydrogenase and the enzymes catalysing the conversion of protocatechuate into $\beta$-ketoadipyl-CoA was poorly elicited by the wild-type inducer, protocatechuate. A much better inducer was the non-metabolizable compound

Table 5. Enzymatic analysis of strain DP 15, compared with that of the wild-type

Enzyme activities in $\mu$ moles transformed/min./mg. protein.

\begin{tabular}{|c|c|c|c|c|}
\hline \multirow[b]{3}{*}{ Enzyme } & \multicolumn{4}{|c|}{ Conditions of growth } \\
\hline & \multicolumn{2}{|c|}{ Succinate (20 mm) } & \multicolumn{2}{|c|}{$\begin{array}{c}\text { Succinate }(20 \mathrm{mM})+ \\
\text { protocatechuate }(2 \mathrm{~mm})\end{array}$} \\
\hline & DP 15 & Wild-type & DP 15 & Wild-type \\
\hline $\begin{array}{l}\text { Hydroaromatic } \\
\text { dehydrogenase }\end{array}$ & 0.002 & 0.014 & 0.002 & 0.383 \\
\hline Dehydroquinase & 0.015 & 0.010 & 0.010 & 0.155 \\
\hline $\begin{array}{l}\text { Dehydroshikimate } \\
\text { dehydrase }\end{array}$ & 0.002 & 0.024 & 0.001 & 0.938 \\
\hline $\begin{array}{l}\text { Protocatechuate } \\
\text { oxygenase }\end{array}$ & $<0.00 I$ & 0.004 & $<0.001$ & 0.284 \\
\hline $\begin{array}{l}\text { Carboxymuconate } \\
\text { lactonizing enzyme }\end{array}$ & $<0.001$ & 0.015 & $<0.001$ & $\mathrm{I} \cdot 020$ \\
\hline
\end{tabular}

Table 6. Levels of dehydroquinase and dehydroshikimate dehydrase in cell free extracts of strain POC-5, a regulatory mutant

Organisms were grown on $20 \mathrm{~mm}$-succinate with the indicated compounds at $2 \mathrm{~mm}$. Enzyme activities in $\mu$ moles transformed $/ \mathrm{min}$. $/ \mathrm{mg}$. protein.

\begin{tabular}{llcc} 
& \multicolumn{2}{c}{ Compound added to the culture medium } \\
\cline { 2 - 3 } & None & Protocatechuate & $\begin{array}{c}\text { 3-Hydroxy-4- } \\
\text { methyl-benzoate }\end{array}$ \\
$\begin{array}{l}\text { Dehydroquinase } \\
\begin{array}{c}\text { Dehydroshikimate } \\
\text { dehydrase }\end{array}\end{array}$ & 0.008 & 0.014 & 0.033 \\
& 0.018 & 0.054 & 0.260
\end{tabular}

3-hydroxy-4-methylbenzoate, which acts as an anti-inducer in the wild type (Cánovas, Wheelis \& Stanier,; Cánovas, Johnson \& Wheelis, I968 1968). Dehydroquinase and dehydroshikimate dehydrase behaved similarly in strain POC- 5 as indicated by the experiment summarized in Table 6 . The difference between the two inducers was less clear in the case of dehydroquinase, due to the presence of the non-inducible isoenzyme.

\section{DISCUSSION}

Synthesis of dehydroquinase and dehydroshikimate dehydrase in Acinetobacter calcoaceticus is product-induced by protocatechuate like the synthesis of the hydroaromatic dehydrogenase (Tresguerres, de Torrontegui et al. 1970). Product-induction of pathways for the dissimilation of compounds which also have important functions in cellular intermediary 
metabolism can be regarded as a device which helps to minimize destruction of the compounds in question when they are formed endogenously as biosynthetic intermediates (Cánovas, Wheelis \& Stanier, 1968). This hypothesis is in agreement with the situation reported here, because both 5-dehydroquinate and 5-dehydroshikimate, the substrates of dehydroquinase and dehydroshikimate dehydrase play an important biosynthetic role as intermediates in the synthesis of aromatic compounds.

The five enzymes which mediate the conversion of protocatechuate to $\beta$-ketoadipyl-CoA and the hydroaromatic dehydrogenase are controlled in Acinetobacter calco-aceticus by a common repressor, as well as by a common inducer (Cánovas, Johnson \& Wheelis, I968; Cánovas, Wheelis \& Stanier, 1968; Tresguerres, de Torrentégui et al. 1970). The behaviour of NP9 and its revertants supports this view, showing also that the two other enzymes of the hydroaromatic pathway not previously studied are also controlled by the same genetic system. There is little information about the linkage relationships among the structural genes of this system. A significant proportion (approx. $1 \%$ ) of the nitrosoguanidine-induced mutants isolated from $2 \mathrm{P}$ with restored protocatechuate oxygenase activity, had simultaneously lost either hydroaromatic dehydrogenase or inducible dehydroquinase, suggesting some association of the three genes (Guerola et al. I97I). The behaviour of DP I 5 and NP 3 for the most part suggest that they harbour a frame-shift mutation, indicating some association of the genes governed by protocatechuate.

The occurrence in Acinetobacter calco-aceticus of a second inducible dehydroquinase isoenzyme distinct from the biosynthetic dehydroquinase, ensures the completely independent operation of the hydroaromatic catabolic pathway. The enzymes of the polyaromatic synthetic pathway are aggregated in fungi (Ahmed \& Giles, 1969), probably to channel intermediates of this pathway, and so segregate them from the hydroaromatic enzymes. The total inability of $A$. calco-aceticus mutants with deficient inducible dehydroquinase, not only to grow on quinate but even to produce enough protocatechuate to induce catabolic enzymes (Table 2), suggests that common intermediates in both pathways may also be somehow segregated in this bacterium.

We are grateful to Miss Maria D. Alcain for her capable technical help. This work was performed during the tenure of M. E. F. Tresguerres of a 'Beca del Ministerio de Educación y Ciencia de España' and by W. M. Ingledew of a National Research Council of Canada Postdoctoral Fellowship. The authors are pleased to acknowledge the financial help provided by the Division Farmacéutica Lepetit.

\section{REFERENCES}

AhMED, S. I. \& Giles, N. H. (I969). Organization of enzymes in the common aromatic synthetic pathway: evidence for aggregation in fungi. Journal of Bacteriology 99, 23I-237.

Arnon, D. I., Das, V. S. R. \& Anderson, J. D. (1963). Studies on Microalgae and Photosynthetic Bacteria, p. 529. Edited by The Japanese Society of Plant Physiologists. Tokyo: The University of Tokyo Press.

Berlyn, M. B. \& Giles, N. H. (I969). Organization of enzymes in the polyaromatic synthetic pathway: separability in bacteria. Journal of Bacteriology 99, 222-230.

CÁnovas, J. L. \& Johnson, B. F. (I968). Regulation of the enzymes of the $\beta$-ketoadipate pathway in Moraxella calco-acetica. IV. Constitutive synthesis of $\beta$-ketoadipate succinyl-CoA transferases II and III. European Journal of Biochemistry 3, 312-317.

Cánovas, J. L., Johnson, B. F. \& Wheelis, M. L. (I968). Regulation of the enzymes of the $\beta$-ketoadipate pathway in Moraxella calco-acetica. III. Effects of 3-hydroxy-4-methylbenzoate on the synthesis of enzymes of the protocatechuate branch. European Journal of Biochemistry 3, 305-3 I I.

CÁnovas, J. L. \& Stanier, R. Y. (I967). Regulation of the enzymes of the $\beta$-ketoadipate pathway in Moraxella calco-acetica. I. General Aspects. European Journal of Biochemistry I, 289-300. 
Cánovas, J. L., Wheelis, M. L. \& Stanier, R. Y. (I968). Regulation of the enzymes of the $\beta$-ketoadipate pathway in Moraxella calcoacetica. II. The role of protocatechuate as inducer. European Journal of Biochemistry 3, 293-304.

Gross, S. R. (1958). The enzymatic conversion of 5-dehydroshikimic acid to protocatechuic acid. Journal of Biological Chemistry 233, I1 46-I I 51 .

Guerola, N., Ingraham, J. L. \& Cerdá-Olmedo, E. (I97I). Induction of closely linked multiple mutations by nitrosoguanidine. Nature, London 230, I 22-1 25.

Haslam, E., Haworth, R. D. \& KNowles, P. F. (1963). The preparations and identification of 5-dehydroquinic and 5-dehydroshikimic acids. In Methods in Enzymology, vol. 4, pp. 498-50I. Edited by S. P. Colowick \& N. O. Kaplan. New York: Academic Press.

Hattori, S., Yoshida, S. \& Hasegawa, M. (1958). Biological conversion of shikimic acid. Archives of Biochemistry and Biophysics 74, 480-482.

Lowry, O. H., Rosebrough, N. J., Farr, A. L. \& Randall, R. J. (1951). Protein measurement with the Folin phenol reagent. Journal of Biological Chemistry 193, 265-275.

Mitsuhashi, S. \& Davis, B. D. (I954a). Aromatic biosynthesis. XII. Conversion of 5-dehydroquinic acid to 5-dehydroshikimic acid by 5-dehydroquinase. Biochemica et biophysica acta 15, 54-61.

Mitsuhashi, S. \& Davis, B. D. (1954b). Aromatic biosynthesis. XIII. Conversion of quinic acid to 5-dehydroquinic acid by quinic dehydrogenase. Biochimica et biophysica acta 15, 268-280.

RoGoff, M. H. (1958). An aromatic intermediate in the bacterial oxidation of quinic acid. Journal of General Microbiology 19, 330-339.

Tatum, E. L., Gross, S. R., Ehrensvärd, G. \& Garnjobst, L. (I954). Synthesis of aromatic compounds by Neurospora. Proceedings of the National Academy of Sciences U.S.A. 40, 271-276.

Tresguerres, M. E. F., de Torrontegui, G. \& Cánovas, J. L. (I970). The metabolism of quinate by Acinetobacter calco-aceticus. Archiv für Mikrobiologie 7o, I I0-1 18.

Tresguerres, M. E. F., De Torrontegui, G., Ingledew, W. M. \& Cánovas, J. L. (I970). Regulation of the $\beta$-ketoadipate pathway in Moraxella. Control of quinate oxidation by protocatechuate. European Journal of Biochemistry 14, 445-450.

YANO, K. \& ARIMA, K. (1958). Metabolism of aromatic compounds by bacteria. II. $m$-Hydroxybenzoic acid hydroxylase $\mathrm{A}$ and $\mathrm{B}$; 5-clehydroshikimic acid, a precursor of protocatechuic acid, a new pathway from salicylic to gentisic acid. Journal of General Applied Microbiology, Tokyo 4, 24I-254.

YoshIDA, S. (1964). Metabolism of shikimic acid and quinic acid in Pseudomonas ovalis. Botany Magazine, Tokyo 77, I0-16. 